\title{
EFEKTIVITAS SEKOLAH LAPANG IKLIM STASIUN KLIMATOLOGI DELI SERDANG DALAM MENDUKUNG KETAHANAN PANGAN
}

\author{
Juliana Sari Kembaren \\ Universitas Sumatera Utara, Medan, Indonesia \\ Balai Besar Meteorologi, Klimatologi dan Geofisika Wilayah I Medan, Indonesia \\ Email: juli_kembaren@gmail.com
}

DOI: https://doi.org/10.46880/jmika.Vol5No2.pp155-161

\begin{abstract}
The purpose of this study was to analyze the effect of SLI activities on the climate adaptive behavior of farmers to support food security in Deli Serdang Regency. The researcher used a quantitative approach with the correlational method. The population is all farmers of the Paluh Getah II Farmer Group, Tanjung Rejo Village, Percut Sei Tuan District, Deli Serdang Regency. The research sample was 56 respondents using the total sample technique. Data collection techniques were carried out through questionnaires. The results showed that there was an effect of SLI activities in the form of conveying information about climate and weather and their deviations, farming innovation, technology transfer and farming analysis able to change the climate adaptive behavior of SLI farmers at Deli Serdang Climatology Station to reduce the risk of crop failure due to extreme weather so that food security can be realized. This is evidenced by the value of $t$ arithmetic $>t$ table which is $3.144>2.586$ at a significance level of 0.05 .
\end{abstract}

Keyword: Sekolah Lapangan Iklim (SLI), Climatology Station, Deli Serdang, Farming Innovation, Technology Transfer.

\begin{abstract}
ABSTRAK
Tujuan penelitian ini adalah untuk menganalisis pengaruh kegiatan SLI terhadap perilaku adaptif iklim petani guna mendukung ketahanan pangan di Kabupaten Deli Serdang. Peneliti menggunakan pendekatan kuantitatif dengan metode korelasional. Populasi adalah seluruh petani Kelompok Tani Paluh Getah II Desa Tanjung Rejo Kecamatan Percut Sei Tuan Kabupaten Deli Serdang. Sampel penelitian sebanyak 56 responden dengan menggunakan teknik sampel total. Teknik pengumpulan data dilakukan melalui kuesioner. Hasil penelitian menunjukkan bahwa terdapat pengaruh kegiatan SLI berupa penyampaian informasi tentang iklim dan cuaca serta penyimpangannya, inovasi bertani, alih teknologi serta analisis usaha tani mampu mengubah perilaku adaptif iklim petani SLI Stasiun Klimatologi Deli Serdang guna menekan terjadinya resiko gagal panen akibat cuaca ekstrim sehingga ketahanan pangan dapat terwujud. Hal ini dibuktikan dengan nilai $\mathrm{t}$ hitung $>\mathrm{t}$ tabel yaitu 3,144 $>2,586$ pada tingkat signifikansi 0,05 .
\end{abstract}

Kata Kunci: Sekolah Lapangan Iklim (SLI), Stasiun Klimatologi, Deli Serdang, Inovasi Bertani, Alih Teknologi.

\section{PENDAHULUAN}

Bagi Indonesia, pangan sering diidentikkan dengan beras karena jenis pangan ini merupakan makanan pokok utamanya. Pengalaman telah membuktikan kepada kita bahwa gangguan pada ketahanan pangan seperti meroketnya kenaikan harga beras pada waktu krisis ekonomi 1997/1998, yang berkembang menjadi krisis multidimensi, telah memicu kerawanan sosial yang membahayakan stabilitas ekonomi dan stabilitas Nasional. Nilai strategis beras juga disebabkan karena beras adalah makanan pokok paling penting. Industri perberasan memiliki pengaruh yang besar dalam bidang ekonomi (dalam hal penyerapan tenaga kerja, pertumbuhan dan dinamika ekonomi perdesaan, sebagai wage good), lingkungan (menjaga tata guna air dan kebersihan udara) dan sosial politik (sebagai perekat bangsa, mewujudkan ketertiban dan keamanan). Dengan pertimbangan pentingnya beras tersebut, Pemerintah selalu berupaya untuk meningkatkan ketahanan pangan terutama yang bersumber dari peningkatan produksi dalam negeri. Pertimbangan tersebut menjadi semakin penting bagi Indonesia karena jumlah penduduknya semakin besar dengan sebaran populasi yang luas dan cakupan geografis yang tersebar. 
Untuk memenuhi kebutuhan pangan penduduknya, Indonesia memerlukan ketersediaan pangan dalam jumlah mencukupi dan tersebar, yang memenuhi kecukupan konsumsi maupun stok nasional yang cukup sesuai persyaratan operasional logistik yang luas dan tersebar. Indonesia harus menjaga ketahanan pangannya. Keseriusan Pemerintah dalam mewujudkan ketahanan pangan juga direalisasikan dalam bentuk Instruksi Presiden Nomor 5 Tahun 2011 tentang "Pengamanan Produksi Beras Nasional dalam Menghadapi Iklim Ekstrim. Melalui instruksi ini dilaksanakan upaya mengamankan produksi gabah/beras nasional serta antisipasi dan respon cepat untuk menghadapi kondisi iklim ekstrim, dengan menginstruksikan 11 (Sebelas) Menteri, Kepala Kepolisian Negara Republik Indonesia, Panglima Tentara Nasional Indonesia, 3 (Tiga) Kepala Badan serta Gubernur dan Bupati. Mengacu pada Instruksi Presiden tersebut, maka Badan Meteorologi Klimatologi dan Geofisika (BMKG) berkepentingan untuk membangun pengetahuan petani tentang iklim dan kemampuan antisipasi dampak kejadian iklim ekstrim terhadap kegiatan pertanian melalui Kegiatan Sekolah Lapang Iklim (SLI).

Pembangunan teknologi yang dilakukan pemerintah haruslah sejalan dengan penyampaian informasi mengenai teknologi yang dibangun tersebut agar menjadi tepat guna bagi masyarakatnya. Pemanfaatan teknologi informasi iklim kepada masyarakat disampaikan pemerintah melalui BMKG, yang salah satunya adalah kegiatan Sekolah Lapang Iklim.

Sekolah Lapang Iklim (SLI) merupakan suatu bentuk pendidikan non formal, yang pendekatannya melalui komunikasi penyuluhan dan pemberdayaan petani untuk memahami dan memanfaatkan informasi iklim secara efektif dalam mendukung pertanian. Tema yang diangkat dalam pelaksanan Kegiatan SLI adalah "Informasi Iklim Yang Cepat, Tepat, Akurat, Luas dan Mudah Dipahami untuk Mendukung Ketahanan Pangan. Pemberian tambahan pengetahuan tentang iklim kepada para petani, tidak bermaksud menghilangkan local wisdom (kearifan lokal) yang menjadi kebiasaan selama ini. Namun, pengetahuan tentang iklim berbasis ilmu pengetahun dan teknologi akan makin memperkuat dan menambah wawasan serta pengetahun petani terhadap iklim. Petani harus waspada cuaca dan peduli iklim sehingga bisa menyesuaikan pola tanam untuk keberhasilan panen. "Komunikasi pembangunan dituntut untuk bisa menyelami konteks gocal (globalization and local). Artinya perkembangan yang ada sekarang tidak lagi hanya globalisasi (mendunia), tetapi harus berintegrasi dengan konteks lokal (salah satunya kearifan lokal), tidak cukup hanya perspektif internasional, tetapi perlu disertai perspektif lokal" (Harun \& Ardianto, 2011).

Stasiun Klimatologi Deli Serdang yang merupakan Unit Pelaksana Teknis (UPT) yang menjadi perpanjangan tangan dari BMKG, melalui Daftar Isian Pelaksanaan Anggaran (DIPA) setiap tahunnya sejak tahun 2012 diberi kepercayaan untuk melaksanakan kegiatan Sekolah Lapang Iklim di Provinsi Sumatera Utara. Berdasarkan rekapitulasi data Stasiun Klimatologi Deli Serdang, kegiatan SLI pernah dilaksanakan di Kabupaten Deli Serdang pada tahun 2013, kepada Kelompok Tani Paluh Getah II di Desa Tanjung Rejo Kecamatan Percut Sei Tuan Kabupaten Deli Serdang dengan metode pembelajaran secara tatap muka langsung di lahan sawah sebanyak 10 (Sepuluh) petemuan dengan interval waktu 10 hari atau selama 4 bulan dalam satu musim tanam. Kelompok tani ini adalah pemilik lahan pertanian yang mereka olah sendiri secara langsung.

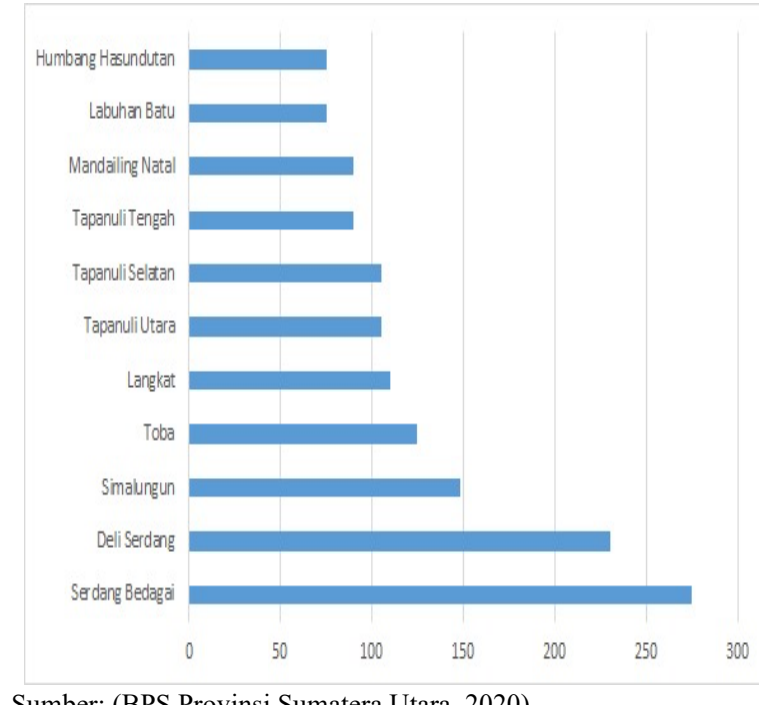

Sumber: (BPS Provinsi Sumatera Utara, 2020)

Gambar 1. Grafik Produksi Padi Sawah dan Padi Kabupaten/Kota (Ribu Ton)

Kabupaten Deli Serdang dijadikan lokus pelaksanaan kegiatan SLI mengingat kabupaten ini merupakan salah satu sentra pangan nasional. Sebagai salah satu lumbung padi nasional, Kabupaten Deli Serdang merupakan produsen padi terbesar di Provinsi Sumatera Utara di tengah berbagai hambatan yang dihadapi pertanian tanaman pangan (BPS Provinsi Sumatera Utara, 2020) 


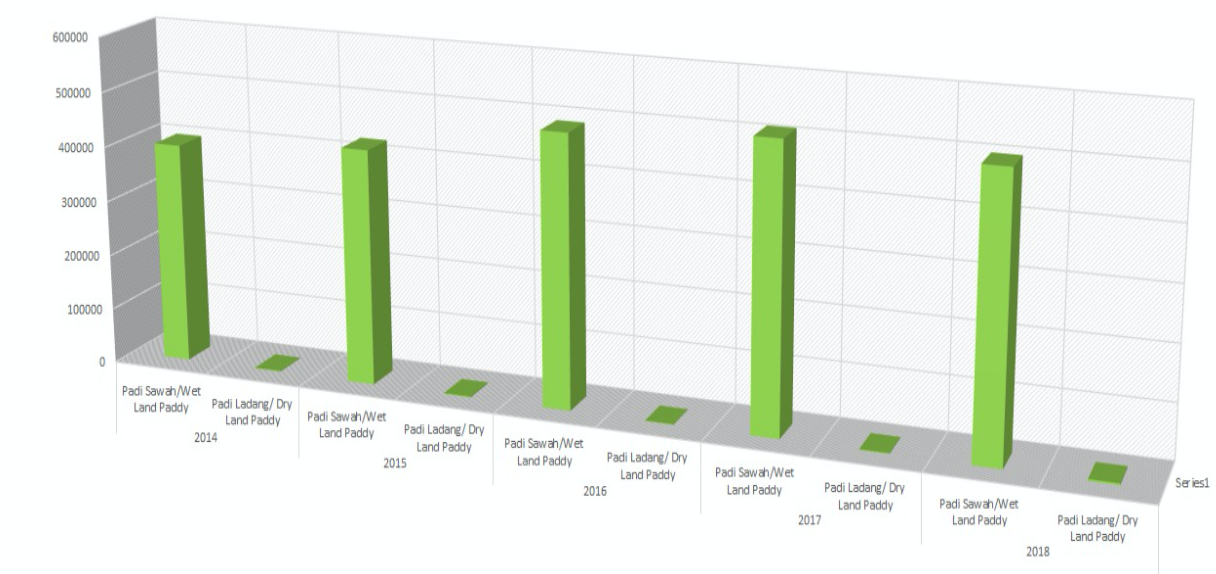

Sumber: (BPS Kabupaten Deli Serdang, 2019)

Gambar 2. Grafik Produksi Padi Sawah dan Padi Ladang Kabupaten Deli Serdang (Ton) Periode 2014-2018

Pada tahun 2018 perkiraan produksi padi sawah di Deli Serdang mencapai 501.208,24 ton dengan ratarata produksi $58,27 \mathrm{kw} / \mathrm{ha}$. Produksi padi ladang sebesar 3.331,31 ton. Hal ini menunjukkan adanya penurunan produksi padi di Kabupaten Deli Serdang (BPS Deli Serdang, 2019:11) [3], kejadian ini menjadi hal yang menarik untuk dikaji, untuk melihat bagaimana SLI Stasiun Klimatologi Deli Serdang mampu mengubah perilaku adaptif iklim petani dalam hal bercocok tanam padi guna mendukung ketahanan pangan nasional.

Sebagaimana diketahui bahwa Badan Meteorologi Klimatologi dan Geofisika (BMKG) secara rutin menyiapkan informasi iklim, seperti Prakiraan Musim Hujan/Kemarau, Evaluasi dan Prakiraan Hujan Bulanan, serta Ketersediaan Air Tanah Bulanan yang diharapkan dapat bermanfaat untuk mendukung berbagai kegiatan terutama sektor pertanian. Metode penyampaian materi melalui tatap muka dengan presentasi instruktur dan simulasi sebagai gambaran sederhana serta peran aktif dalam diskusi dari tiap-tiap materi yang diberikan. Materi SLI meliputi: Pengenalan Cuaca dan Iklim serta alat ukurnya, Proses Pembentukan Awan dan Hujan, Iklim Ekstrim, Memahami Informasi Iklim serta Pemanfaatannya dan Analisa sederhana usaha tani. Inovasi pembelajaran melalui SLI diharapkan mampu menjadi solusi bagi salah satu penyebab kegagalan panen, sehingga melalui informasi yang disampaikan oleh BMKG mampu meminalisir gagal panen padi akibat cuaca ekstrim sehingga ketahanan pangan dapat terwujud. Fakta yang terjadi di lapangan dan mengingat anomali cuaca yang berlangsung, maka perlu dilaksanakan penelitian untuk menganalisis pengaruh kegiatan SLI terhadap perilaku adaptif iklim petani guna mendukung ketahanan pangan di Kabupaten Deli Serdang.

\section{METODE PENELITIAN}

Metode yang digunakan peneliti dalam penelitian ini adalah metode penelitian kuantitatif. Suatu pembuktian/pengujian yang dimulai dengan teori-teori atau hipotesis dengan menggunakan pendekatan korelasional (Kasmadi \& Sunariah, 2013) Metode dalam penelitian ini berlandaskan filosofi positivisme, peran peneliti terbatas pada pengumpulan dan interpretasi data melalui pendekatan objektif dan hasil penilitian dapat diamati dan diukur (Lubis, Manaf, Ahmad, Abdullah, \& Junoh, 2019).

Pendekatan obyektif ini harus didasarkan atas informasi yang kita peroleh dalam penelitian kita, dan didasarkan atas risiko yang sanggup kita tanggung bahwa keputusan kita sehubungan dengan hipotesis itu bisa menjadi tidak benar (Siegel, 2018). Maka dari uraian tersebut dapat ditarik hipotesis penelitian ini, sebagai berikut:

Hipotesis kerja yang dirumuskan dalam penelitian ini sebagai berikut:

$\mathrm{H}_{0}$ : Tidak terdapat pengaruh efektivitas komunikasi penyuluhan kegiatan SLI terhadap perilaku adaptif iklim guna mendukung ketahanan pangan di kalangan petani Kelompok Tani Paluh Getah II Kec. Percut Sei Tuan Kab. Deli Serdang.

$\mathrm{H}_{\mathrm{a}}$ : Terdapat pengaruh efektivitas komunikasi penyuluhan kegiatan SLI terhadap perilaku adaptif iklim guna mendukung ketahanan pangan di kalangan petani Kelompok Tani Paluh Getah II Kec. Percut Sei Tuan Kab. Deli Serdang.

Data dalam penelitian ini diperoleh melalui perhitungan ilmiah dengan penggunaan skala likert. Data bersumber dari responden yang diminta untuk 
menjawab sejumlah pernyataan yang disajikan dalam bentuk kuesioner guna penentuan frekuensi dan presentase tanggapan responden. Data yang diperoleh digunakan untuk mengetahui pengaruh kegiatan SLI dalam mendukung ketahanan pangan di Kabupaten Deli Serdang.

Kelompok Tani Paluh Getah II yang beralamat di Desa Tanjung Rejo Kecamatan Percut Sei Tuan Kabupaten Deli Serdang ditetapkan peneliti sebagai lokasi penelitian. Penetapan lokasi ini didasarkan kepada data dari Stasiun Klimatologi Deli Serdang bahwa kelompok Tani Paluh Getah II telah mendapatkan penyuluhan adaptasi iklim terhadap petani melalui kegiatan Sekolah Lapang Iklim pada Tahun 2013. Penelitian ini terdapat dua variabel yang akan diteliti, yaitu variabel kegiatan sli (X), variabel perilaku adaptif iklim petani guna mendukung ketahanan pangan $(\mathrm{Y})$.

Tabel 1. Pemberian Skor Skala Likert

\begin{tabular}{|l|c|c|}
\hline \multirow{2}{*}{ Pilihan Jawaban } & \multicolumn{2}{|c|}{ Item Pernyataan } \\
\cline { 2 - 3 } & $\begin{array}{c}\text { Favourable) } \\
\text { Positif }\end{array}$ & $\begin{array}{c}\text { Unfavourable } \\
\text { Negatif }\end{array}$ \\
\cline { 2 - 3 } & Skor & Skor \\
\hline $\begin{array}{l}\text { Sangat Setuju } \\
\text { (SS) }\end{array}$ & 5 & 1 \\
\hline Setuju (S) & 4 & 2 \\
\hline $\begin{array}{l}\text { Kurang Setuju } \\
\text { (KS) }\end{array}$ & 3 & 3 \\
\hline Tidak Setuju (TS) & 2 & 4 \\
\hline $\begin{array}{l}\text { Sangat Tidak } \\
\text { Setuju (STS) }\end{array}$ & 1 & 5 \\
\hline
\end{tabular}

Pada penelitian ini, populasi penelitian homogen yaitu Kelompok Tani Paluh Getah II Desa Tanjung Rejo Kecamtan Percut Sei Tuan Kabupaten Deli Serdang dengan anggota populasi sebanyak 56 orang, hal ini memungkinkan peneliti untuk menjadikan semua anggota populasi menjadi sampel penelitian.

Penelitian ini menggunakan metode kuesioner dalam proses pengumpulan datanya, dimana daftar pertanyaan sebanyak 50 item yang telah terstruktur dalam kuesioner disebarkan pada semua anggota Kelompok Tani. Secara umum, validitas riset kuantitatif terletak pada penentuan metodologinya (Bungin, 2014). Pengujian validitas dan realibilitas menggunakan bantuan SPSS (Statistical Package for Social Sciences) for Windows versi 28. Hasil pengujian validitas untuk masing-masing item pernyataan yang valid dari setiap variabel independen dan variabel dependen yang diuji dengan nilai $\mathbf{r}_{\text {tabel }}=0,259$ dengan jumlah responden sebanyak 56 orang pada tingkat signifikansi $\alpha=0,05$ sehingga dinyatakan valid. hasil uji realibilitas untuk variabel Kegiatan SLI (X) memiliki nilai Cronbach Alpha sebesar 0,895 yang melewati syarat batas minimum 0,60 , hal ini juga berlaku untuk variabel Perilaku Adaptif Iklim Petani guna mendrukung ketahanan pangan (Y) yang memiliki nilai Cronbach Alpha yang lebih besar dari 0,60 yaitu sebesar 0,788 . Dengan demikian dapat didefinisikan bahwa item-item pernyataan layak untuk dijadikan sebagai instrumen penelitian dan dapat disebarkan kepada responden.

Teknik analisa data mengguanakan analisa regresi dan uji hipotesis. Analisis regresi sederhana digunakan untuk memprediksi variabel $\mathrm{Y}$ dari variabel $\mathrm{X}$. Analisis regresi digunakan untuk memprediksi variabel Y jika variabel X dimanipulasi (Kasmadi \& Sunariah, 2013). Penelitian ini menggunakan regresi linear sederhana dikarenakan hanya memprediksi hubungan diantara dua variabel yaitu variabel । kegiatan SLI (X) terhadap variabel perilaku adaptif iklim petani guna mendukung ketahanan pangan (Y) dengan menggunakan aplikasi SPSS for Windows versi 28 maka dapat dirumuskan sebagai berikut (Siswanto \& Suyanto, 2018):

Dimana:

$$
\mathrm{Y}=\mathrm{a}+\mathrm{b} \cdot \mathrm{X}
$$

$\mathrm{Y}=$ variabel dependen (perilaku adaptif iklim guna mendukung ketahanan pangan)

$=$ bilangan konstanta, nilai $\mathrm{Y}$ jika $\mathrm{X}=0$

$=$ koefisien regresi linier sederhana

$=$ variabel independen (kegiatan SLI)

Setelah penentuan nilai korelasi antara variabel independen (X) terhadap variabel dependen (Y), kemudaian dilakukan pengujian hipotesis dilakukan untuk mengetahui apakah terdapat pengaruh yang signifikan antara variabel independen dengan variabel dependen. Uji signifikansi dilakukan untuk melihat apakah variabel independen memiliki pengaruh signifikan terhadap variabel dependen.

\section{Uji signifikan (t-test)}

Digunakan untuk mengetahui seberapa besar pengaruh kegiatan SLI terhadap perilaku adaptif petani secara parsial dengan rumus sebagai berikut:

Keterangan:

$$
t=\frac{r \sqrt{n-2}}{\sqrt{1-r^{2}}}
$$

$\mathrm{r}=$ koefisien korelasi variabel $\mathrm{x}$ dan $\mathrm{y}$ 
$\mathrm{n}=$ jumlah sampel

$\mathrm{t}=$ test signifikan

Model hipotesis yang digunakan adalah:

$\mathrm{H}_{0}: \mathrm{x}=0$, artinya variabel independen yaitu kegiatan SLI (X) secara parsial tidak berpengaruh signifikan terhadap variabel dependen yaitu perilaku adaptif iklim guna mendukung ketahanan pangan (Y).

$\mathrm{H}_{\mathrm{a}}: \mathrm{x} \neq 0$, artinya kegiatan SLI (X) secara parsial berpengaruh positif dan signifikan terhadap variabel dependen yaitu perilaku adaptif iklim guna mendukung ketahanan pangan (Y).

Kriteria pengambilan keputusan:

$\mathrm{H}_{0}$ diterima jika thitung $<\mathrm{t}_{\text {tabel }}$ pada $\alpha=5 \%$

$\mathrm{H}_{0}$ ditolak jika thitung $>$ tabel pada $\alpha=5 \%$

\section{HASIL DAN PEMBAHASAN}

Analisa Regresi

Hasil uji regresi linear sederhana akan ditunjukkan pada tabel 2 dibawah ini.

Tabel 2. Hasil Indeks Determinasi Regresi Sederhana

\begin{tabular}{|l|r|r|r|r|}
\hline Model & R & R Square & Adjusted R Square & Std. Error of the Estimate \\
\hline 1 & $.393^{\mathrm{a}}$ & 0.155 & 0.139 & 4.89506 \\
\hline
\end{tabular}

Dari tabel 2 diketahui nilai koefisien deterninasi $\mathrm{R}^{2}$ ( $\mathrm{R}$ square) sebesar 0,155 sehingga dapat dihitung indeks determinasi sebagai berikut:

$\mathrm{Kd}=\mathrm{R}^{2} \times 100 \%$

$\mathrm{Kd}=0,155 \times 100 \%$

$\mathrm{Kd}=15,5 \%$;
Dari hasil perhitungan menunjukkan bahwa pemberian inovasi pada kegiatan SLI berpengaruh terhadap perilaku adaptif iklim guna mendukung ketahanan pangan sebesar $15,5 \%$ dan sisanya $84,5 \%$ dipengaruhi oleh faktor lain yang tidak diteliti dalam penelitian ini. R square berkisar pada angka 0 sampai 1, semakin kecil nilai $\mathrm{R}$ square maka semakin lemah hubungan antara variable $\mathrm{X}$ dan $\mathrm{Y}$.

Tabel 3. Hasil Koefisien Regresi Sederhana dan Signifikansi (Uji-t)

\begin{tabular}{|c|c|c|c|c|c|c|}
\hline & \multirow{2}{*}{ Model } & \multicolumn{2}{|c|}{$\begin{array}{c}\text { Unstandardized } \\
\text { Coefficients }\end{array}$} & \multirow{2}{*}{$\begin{array}{c}\begin{array}{c}\text { Standardized } \\
\text { Coefficients }\end{array} \\
\text { Beta }\end{array}$} & \multirow{2}{*}{$\mathbf{T}$} & \multirow{2}{*}{ Sig. } \\
\hline & & B & $\begin{array}{c}\text { Std. } \\
\text { Error }\end{array}$ & & & \\
\hline \multirow[t]{2}{*}{1} & (Constant) & 72.855 & 10.578 & & 6.887 & 0.000 \\
\hline & Kegiatan SLI & 0.320 & 0.102 & 0.393 & 3.144 & 0.003 \\
\hline
\end{tabular}

Berdasarkan hasil pengolahan data dengan program SPSS 28 pada tabel di atas didapat model persamaan regresi linier sederhana sebagai berikut:

$$
\mathrm{Y}=72,855+0,320 \mathrm{X}
$$

Dari persamaan tersebut dapat diketahui bahwa:

1) Nilai konstanta (a) sebesar 72,855 menunjukkan bahwa jika tidak ada kenaikan kegiatan SLI (X) maka nilai konstanta perilaku adaptif iklim guna mendukung ketahanan pangan (Y) adalah sebesar 72,855 .

2) Angka koefisien regresi (b) sebesar 0,320 menyatakan bahwa setiap ada penambahan (karena tanda positif) 1 angka untuk ] kegiatan SLI (X), maka perilaku adaptif iklim guna mendukung ketahanan pangan (Y) akan meningkat sebesar 0,320 . Koefisien regresi yang bernilai positif $(+)$ menandakan bahwa semakin tinggi nilai nilai inovasi dan alih teknologi kegiatan SLI maka semakin tinggi pula nilai perilaku adaptif iklim yang dilaksanakan oleh petani untuk mendukung ketahanan pangan, begitu pula sebaliknya semakin rendah nilai $\backslash$ kegiatan SLI maka semakin rendah pula perilaku adaptif iklim.

\section{Uji Hipotesis}

Uji t dilakukan untuk menguji secara parsial apakah variabel kegiatan SLI (X) berpengaruh signifikan terhadap perilaku adaptif iklim (Y). Model hipotesis yang digunakan adalah:

$\mathrm{H}_{0}: \mathrm{b}_{1}=\mathrm{b}_{2}=0$, artinya variabel kegiatan SLI (X)tidak 
berpengaruh signifikan pada variabel perilaku adaptif iklim guna mendukung ketahanan pangan $(\mathrm{Y})$.

$\mathrm{H}_{0}: \mathrm{b} 1 \neq \mathrm{b} 2 \neq 0, \quad$ artinya variabel kegiatan SLI $(\mathrm{X})$ berpengaruh positif terhadap variabel perilaku adaptif iklim guna mendukung ketahanan pangan $(\mathrm{Y})$.

Kriteria pengambilan keputusan:

$\mathrm{H}_{0}$ diterima apabila thitung $<$ tabel pada $\alpha=5 \%$

$\mathrm{H}_{0}$ ditolak apabila thitung $>$ tabel pada $\alpha=5 \%$

Tabel 4. Hasil Koefisien Regresi Berganda dan Signifikansi (Uji-t)

\begin{tabular}{|l|l|r|r|r|r|r|}
\hline \multirow{2}{*}{\multicolumn{2}{|c|}{ Model }} & \multicolumn{1}{c|}{$\begin{array}{c}\text { Unstandardized } \\
\text { Coefficients }\end{array}$} & $\begin{array}{c}\text { Standardized } \\
\text { Coefficients }\end{array}$ & \multirow{2}{*}{ T } & \multirow{2}{*}{ Sig. } \\
\cline { 3 - 5 } & \multicolumn{1}{|c|}{ B } & Std. Error & \multicolumn{1}{c|}{ Beta } & & \\
\hline \multirow{2}{*}{1} & $($ Constant $)$ & 72.855 & 10.578 & & 6.887 & 0.000 \\
\cline { 2 - 6 } & Kegiatan SLI & 0.320 & 0.102 & 0.393 & 3.144 & 0.003 \\
\hline
\end{tabular}

Dari hasil pengolahan data dengan menggunakan software SPSS 28.0 yang terdapat pada tabel 4, diketahui nilai t hitung untuk variabel kegiatan SLI adalah 3,144. Kemudian akan dibandingkan dengan nilai tabel pada tingkat $\alpha=5 \%$ yakni yang diperoleh dengan derajat bebas $=\mathrm{df}-\mathrm{k}(\mathrm{df}=$ jumlah sampel dan $\mathrm{k}=$ jumlah semua variabel). Ditentukan $\mathrm{df}_{1}$ $=2-1=1$, dan $\mathrm{df}_{2}=56-2=54$. Berdasarkan derajat bebas tersebut dengan uji dua arah maka tabel yang digunakan adalah $\mathrm{t} \alpha=0,05(1 ; 54)=2,00488$. Sehingga dapat dinyatakan bahwa thitung $>t_{\text {tabel }}(3,144>2,00488)$ yang menunjukkan bahwa kegiatan SLI memiliki kontribusi terhadap perilaku adaptif iklim guna mendukung ketahanan pangan. Nilai t yang positif $(+)$ menunjukkan bahwa kegiatan SLI mempunyai hubungan yang searah dengan perilaku adaptif iklim. Artinya jika ditingkatkan variabel efektivitas komunikasi penyuluhan kegiatan SLI (X) sebesar satu satuan maka perilaku adaptif iklim (Y) akan meningkat sebesar 3,144 satuan.

Berdasarkan tabel 4 dapat dilihat nilai signifikansi (Sig.) lebih kecil dari probabilitas 0,05. Nilai Sig. $0,003<0,05$, maka $\mathrm{H}_{0}$ ditolak dan $\mathrm{H}_{a}$ diterima. Sehingga dari hasil perhitungan regresi dengan melihat thitung dan nilai Sig. dapat disimpulkan bahwa hasil uji hipotesis diterima. Hal ini berarti terdapat pengaruh secara positif dan signifikan antara kegiatan SLI terhadap perilaku adaptif iklim guna mendukung ketahanan di pangan di kalangan petani peserta SLI Kelompok Tani Paluh Getah II Desa Tanjung Rejo Kecamatan Percut Sei Tuan Kabupaten Deli Serdang.

Berdasarkan temuan penelitian didapat hasil yang menunjukkan kecenderungan hubungan yang positif diantara variabel kegiatan SLI terhadap variabel perilaku adaptif iklim guna mendukung ketahaan pangan. Dimana semakin tinggi indikator-indikator yang terdapat pada variabel kegiatan SLI yaitu metode penyuluhan, narasumber, materi penyuuhan, media penyuluhan dan ketepatan waktu pelaksanaan kegiatan SLI yang dimiliki oleh pegawai Staklim Deli Serdang, maka akan semakin tinggi pula perilaku adaptif iklim petani. Dengan adanya sinergi antara peningkatan efektivitas komunikasi penyuluhan kegiatan SLI untuk menginformasikan tentang tindakan adaptif iklim dalam bercocok tanam padi, mengedukasi terkait dampak dari perubahan iklim terhadap musim tanam dan siklus hidup organisme penganggu tanamam serta melakukan komunikasi persuasif dan intensif terkait strategi penanaman padi, serta analisa usaha tani, akan memberikan persepsi positif dalam benak wajib petani peserta kegiatan SLI yaitu Kelompok Tani Paluh Getah II Desa Tanjung Rejo Kecamatan Percut Sei Tuan Kabupaten Deli Serdang. Hal ini akan membuat petani lebih yakin untuk melakukan tindakan bertani yang adaptif iklim dan dapat lebih membentuk sikap positif pada diri petani. Sehingga dapat disimpulkan adanya kegiatan SLI yang baik yang dilaksanakan oleh ASN Staklim Deli Serdang akan memberikan pengaruh terhadap semakin tingginya keputusan petani untuk melakukan tindakan bertani yang adaptif iklim.

\section{KESIMPULAN}

Kegiatan SLI yang dilaksanakan oleh Stasiun Klimatologi Deli Serdang yang menyebarluaskan infomrasi tentang iklim dan cuaca dan inovasi serta alih teknologi pertanian kepada petani mampu meningkatkan tindakan perilaku bertani yang adaptif iklim di Kabupaten Deli Serdang sehingga menekan terjadinya kegagalan panen akibat cuaca ekstrim yang pada akhirnya dapat mendukung terwujudnya ketahanan pangan. 


\section{DISEMINASI}

Artikel ini telah diseminasikan pada Seminar Nasional Inovasi \& Informatika (SNIIf 2021) yang diselenggarakan oleh Fakultas Ilmu Komputer Universitas Methodist Indonesia pada tanggal 23 Juli 2021.

\section{DAFTAR PUSTAKA}

BPS Kabupaten Deli Serdang. (2019). Statistik Daerah Kabupaten Deli Serdang 2019. Lubuk Pakam.

BPS Provinsi Sumatera Utara. (2020). Provinsi Sumatera Utara Dalam Angka 2020. Medan.

Bungin, B. (2014). Riset Komunikasi Disertai Contoh Praktis Riset Media, Public Relations, Adverstising, Komunkasi Organisasi, Komunikasi Pemasaran. Jakarta: Prenamedia Group.

Harun, R., \& Ardianto, E. (2011). Komunikasi pembangunan dan perubahan sosial. Jakarta: PT Raja Grafindo Persada.

Kasmadi, \& Sunariah, N. S. (2013). Panduan Modern Penelitian Kuantitatif Bacaan Wajib Bagi Peneliti, Guru dan Mahasiswa Program S1 dan S2 di Lingkungan Penidikan. Bandung: Alfabeta.

Lubis, Z., Manaf, A. H. A., Ahmad, H. M. A. H., Abdullah, M. S. zal, \& Junoh, M. Z. M. (2019). No Panduan Pelaksanaan Penelitian Sosial. Yogyakarta: Andi Offset.

Siegel, S. (2018). Statistik Non Parametrik untuk Ilmu-Ilmu Sosial. Jakarta: PT. Gramedia.

Siswanto, \& Suyanto. (2018). No Metodologi Penelitian Kuantitatif Korelasional. Klaten: Bossscript. 